\title{
Psychometric properties of the Portuguese Dutch Work Addiction Scale
}

\author{
Propriedades psicométricas da Dutch Work Addiction Scale portuguesa \\ Propiedades psicométricas de la Dutch Work Addiction Scale portuguesa
}

How to cite this article:

Borges E, Sequeira C, Martins T, Queirós C, Mosteiro-Díaz MP. Psychometric properties of the Portuguese Dutch Work Addiction Scale. Rev Esc Enferm USP. 2021;55:e03765. https://doi.org/10.1590/S1980-220X2020029603765

\author{
Elisabete Borges ${ }^{1}$ \\ Carlos Sequeira ${ }^{1}$ \\ Teresa Martins ${ }^{1}$ \\ Cristina Queirós ${ }^{2}$ \\ Maria Pilar Mosteiro-Díaz ${ }^{3}$ \\ ${ }^{1}$ Escola Superior de Enfermagem do Porto, \\ Center for Health Technology and Services \\ Research (Cintesis), Porto, Portugal. \\ ${ }^{2}$ Faculdade de Psicologia e de Ciências, Educação \\ da Universidade do Porto, Porto, Portugal. \\ ${ }^{3}$ Facultad de Medicina y Ciencias de la \\ Salud, Universidad de Oviedo, Spain.
}

\begin{abstract}
Objective: To analyse the psychometric properties of the Dutch Work Addiction Scale in a sample of Portuguese nurses. Method: A methodological study was conducted with 1,030 Portuguese nurses. A sociodemographic/professional questionnaire and the Dutch Work Addiction Scale applied between October and December 2019. Results: The Confirmatory Factorial Analyses confirmed the factorial structure of two dimensions, namely Working Excessively $(\alpha=.730)$ and Working Compulsively $(\alpha=.752)$, grounded on the theoretical model of workaholism; the reliability values were considered adequate. Nurses presented a moderate level of workaholism, with a higher mean value for Working Excessively. Conclusion: The results raised the issue of workaholism and highlighted the need for further study. The Portuguese version of the DUWAS presented good psychometric characteristics and can be considered a valid and useful instrument to identify this problem.
\end{abstract}

\section{DESCRIPTORS}

Work; Psychometrics; Nurses; Occupational Health; Mental Health. 


\section{INTRODUCTION}

Changes in the workplace, such as the use of technologies and the shift to a green economy ${ }^{(1-2)}$, have had a profound impact on modern society. In recent years, important research conducted in different countries and work contexts has highlighted the growing interest associated with the phenomenon of workaholism ${ }^{(3)}$.

In considering the historical approach of workaholism as a scientific research problem, Oates $(1971)^{(4)}$ describes workaholism as an "uncontrollable need to work incessantly' and a 'person whose need for work has become so excessive that it creates noticeable disturbance or interference with his bodily health, personal happiness, and interpersonal relations, and with his smooth social functioning". In 1992, a workaholic was defined "as a person who exhibits three properties: in comparison to others, the workaholic is highly work involved, feels compelled or driven to work because of inner pressures, and is low in the enjoyment of work" ${ }^{\prime(5)}$. In line with Oates and the theories of addiction (involving the dimensions, affection, cognition, and behaviour), authors proposed a theoretical model and defined workaholics "as those who enjoy the act of working, who are obsessed with working, and who devote long hours and personal time to work" ${ }^{(6)}$. Workaholism is also defined "as the tendency to working excessively hard (the behavioural dimension) and being obsessed with work (the cognitive dimension), which manifests itself in working compulsively"(7). In 2016, workaholism was described

"as an addiction to work that involves feeling compelled or driven to work because of internal pressures, having persistent and frequent thoughts about work when not working, and working beyond what is reasonably expected (as established by the requirements of the job or basic economic needs) despite potential negative consequences ${ }^{(8)}$."

Thus, workaholism is a complex phenomenon that can be triggered by individual factors (e.g. personality traits, gender and age), organizational factors (e.g. job satisfaction, organizational culture and work overload) and socio-cultural factors ${ }^{(6,9)}$. Similarly, the consequences of this phenomenon are often detected in sleep pattern disorders ${ }^{(10)}$, cardiovascular changes $^{(11)}$, anxiety ${ }^{(12)}$, burnout ${ }^{(13)}$, secondary traumatic stress ${ }^{(14)}$, and family conflict ${ }^{(15)}$.

The literature offers several instruments dedicated to investigating workaholism, with the Workaholism Battery $(\text { WorkBAT) })^{(5)}$, the Work Addiction Risk Test (Wart) ${ }^{(16)}$, the Dutch Work Addiction Scale (Duwas) ${ }^{(7)}$ and the Bergen Work Addiction Scale (BWAS) ${ }^{(17)}$ being the most commonly used.

However, the Duwas is a brief and easy scale, based on the WorkBAT ${ }^{(5)}$, and the Wart ${ }^{(16)}$, originally composed of 17 items and two dimensions: Working Excessively (WE, 9 items; 3, 4, 6, 8, 11, 13, 14, 17 and 19), and Working Compulsively (WC, 8 items; 2, 5, 7, 9, 12, 15, 18), assessed through a 4-point Likert scale, ranging between 1 (almost never) and 4 (almost always). Moreover, the WE dimension is originated from the Wart ${ }^{(16)}$ called "control trends", while the WC, derives from WorkBAT ${ }^{(5)}$, called "Drive" ${ }^{(7)}$.

Thus, in line with the definition by Oates (1971) and aiming to overcome limitations evidenced in the WorkBAT, Wart and Duwas 17 items $^{(7)}$, the authors of the Duwas developed the original version of 10 items with samples of workers from Japan $(n=3,311)$ and the Netherlands $(n=7,594)$. Through Confirmatory Factorial Analyses, this version showed a two-factor structure (WE-behavioural component and WC-cognitive component). The internal consistency values found in the Dutch sample were .78 (WE) and .78 (WC), and in the Japanese sample .73 (WE) and .68 (WC). The Duwas is assessed on a 4-point Likert scale (1-Never to 4-Every day), and according to the authors, participants are considered workaholics if scores are equal to or above the 75 th percentile on the combination of WC and WE or for the score of work addiction.

The Duwas has already been applied and validated in other countries, showing good psychometric qualities, thus facilitating its use. For example, in Brazil with a sample of 324 workers $^{(18)}$, Spain with 550 workers ${ }^{(19)}$, Italy with 1,027 workers $^{(20)}$, Argentina with 459 workers ${ }^{(21)}$, and Norway with 661 workers $^{(17)}$. In Portugal, the long version of the Duwas was applied to a sample of 233 workers from the Lisbon region ${ }^{(22)}$ and a study for cross-cultural adaptation and validation was carried out with the short version of the Duwas with a sample of 378 workers, from public, private or self-employed sectors ${ }^{(23)}$ revealing good reliability in assessing workaholism.

With nursing being a crucial occupation in modern societies, and considering that their psychological well-being affects patients and the quality of provided care, this study aims to analyse the psychometric properties of the Duwas ${ }^{(7)}$ in a sample of Portuguese nurses.

\section{METHOD}

\section{Design of study and Population}

A methodological study was conducted with an estimated total population of 60,000 nurses who met the inclusion criteria (equal to or with more than one year of professional experience in Portugal). Sample size calculation was performed using the program for statistical and epidemiological analysis of data (Epidat 4.2). The calculated minimum size (100\% response rate) was 854 nurses, for a 3.0\% accuracy, a $95.0 \%$ confidence level and an expected prevalence of workaholism of $28.3 \%$, with a sample of 1,030 participants considered adequate.

\section{Data collection}

Data gathering was performed using a designed tool which included a sociodemographic and professional questionnaire (gender, age, marital status, presence of children, academic qualifications, workplace, time of professional experience, type of contract and working hours) and the Duwas ${ }^{(7)}$.

In 2009, authors developed a short version of the Duwas consisting of 10 items, distributed between the two dimensions (WE and WC, each with five items), assessed through a 4-point Likert scale ${ }^{(7)}$. This tool has revealed good psychometric qualities in different studies ${ }^{(17-19,24)}$. The 10-item version tested in the present study was developed in 2014 ${ }^{(23)}$. The translation and adaptation to the Portuguese language was carried out in an academic context, following the methodological guidelines ${ }^{(25)}$. The process included translation and retro-translation of the items, analysis and discussion of the versions by a group of 
experts in psychology, and the conduct of a study with a sample of 357 participants to analyse the properties of the experimental version. The analysis of the scale's components was performed through an Exploratory Factorial Analysis, with the extraction of two factors to explain the $49.6 \%$ variance and internal consistency values of the global scale of .82 , the WE .75 and WC $.65^{(23)}$. This present study aims to analyse the adequacy of the theoretical model through Confirmatory Factorial Analysis.

\section{DATA ANALYSIS AND TREATMENT}

Univariate exploratory analysis of the data was performed using descriptive statistical measures, namely measures of central tendency (means and medians), and measures of dispersion (amplitude and standard deviation). The analysis of the reliability of the scale and its dimensions was performed using Cronbach's alpha coefficient, which is calculated based on the mean of the intercorrelations between all the items of the scale. Good internal consistency is reached with an alpha value higher than .80 , but values above .60 are acceptable when only a very low number of items are analysed ${ }^{(26)}$. Concerning the statistical significance, the reference value was set at $5 \%(p<.005)$. These analyses were performed using IBM- SPSS version 25 .

Structural equation analysis was performed through Confirmatory Factorial Analysis (CFA), to test the bifactorial model of the Duwas with 10 items and including the factors: CW (items: 3, 5, 7, 9 and 10) and EW (items: 1, 2, 4, 6 , and 8). This analysis was performed using the IBM-Amos (version 26) software.

The variance of the four factors was set at 1 for the analysis of the significance of all items of each factor and to scale the factors. The covariance matrix was considered as input using the Maximum Likelihood Estimation Method. The existence of outliers was evaluated by the square of the Mahalanobis distance, and normality was calculated through the coefficient of asymmetry and uniand multivariate kurtosis.

The quality of the fit of the model was performed in accordance with the indices and respective reference values ${ }^{(27)}$. The quality of the local fit was assessed by factor weights and the individual reliability of the items. The Comparative Fit
Index (CFI), the Root Mean Squared Residual (RMR), and the Root Mean Square Error Approximation (RMSEA), with its Confidence Intervals (CI) and modification indexes were also considered. The fit of the model considered the theoretical hypothesis.

\section{Procedures}

The Portuguese Order of Nurses helped in the recruitment of the participants by publicizing the study and providing a link for an electronic form, which was made available between October and December 2019, for all nurses willing to participate. The online questionnaire was set up using the LimeSurvey platform. Nurses were invited to participate in the online survey by accessing a link to the questionnaire. The first part of the questionnaire included information about the survey (objectives, population, selection of participants, inclusion criteria, instruments and resources) followed by informed consent. Only after agreeing to participate, could the respondents access and complete the questionnaire (sociodemographic and professional characterization and the Duwas scale).

\section{ETHICAL ASPECTS}

The study was granted approval by the Ethics Committee of a Higher Education Institution (2019/1526). Nurses willing to participate in the study were asked to sign an informed consent before filling out the online questionnaire.

\section{RESULTS}

Of the 1,030 participants, most were female (83\%), married or cohabiting (65\%) and with children (63\%). They had an average age of 39 years ( $\mathrm{SD}=9.9)$, and an average of 16 years $(\mathrm{SD}=10.0)$ professional experience. The majority had a licentiate degree (49\%), worked in hospitals (56\%), had a permanent employment contract (88\%) and performed shift work (55\%).

Table 1 presents mean values, standard deviations, internal consistencies (Cronbach's $\alpha$ ) and the Duwas dimension items (WC and WE), as proposed by the $\operatorname{model}^{(7)}$.

Cronbach's $\alpha$ varied between .730 to WE, .752 to WC and .818 to total scale. According to the average values, the dimension WE scored the highest.

Table 1 - Cronbach Alpha, mean, standard deviation, items of the Duwas, WC and WE - Porto, Portugal, 2019.

\begin{tabular}{|c|c|c|c|c|}
\hline Instrument/dimensions & Items & Cronbach Alpha & Mean & SD* \\
\hline \multirow{5}{*}{ Working Compulsively } & 3- It is important for me to work hard, even when I do not enjoy what I am doing & \multirow{5}{*}{.752} & \multirow{5}{*}{2.05} & \multirow{5}{*}{.56} \\
\hline & 5- I often feel there is something inside me that drives me to work hard & & & \\
\hline & 7-I feel obliged to work hard, even when it is not enjoyable & & & \\
\hline & 9- I feel guilty when I take time off work & & & \\
\hline & 10- It is hard for me to relax when I am not working & & & \\
\hline \multirow{5}{*}{ Working Excessively } & 1 - I seem to be in a hurry and racing against the clock & \multirow{5}{*}{.730} & \multirow{5}{*}{2.64} & \multirow{5}{*}{.52} \\
\hline & 2- I find myself still working after my co-workers have called it quits & & & \\
\hline & 4- I stay busy and keep lots of irons in the fire & & & \\
\hline & 6- I spend more time working than on socializing with friends, on hobbies or leisure activities & & & \\
\hline & $\begin{array}{l}\text { 8- I find myself doing two or three things at one time, such as eating lunch and writing a } \\
\text { memo, while talking on the telephone }\end{array}$ & & & \\
\hline Workaholism & & .818 & 2.35 & .47 \\
\hline
\end{tabular}


The results showed a poor fit of the measurement model with a value of $\mathrm{X}^{2}(34, \mathrm{~N}=1,030)=318.003$, $\mathrm{p}<.0001, \mathrm{RMR}=.038, \mathrm{CFI}=.892, \mathrm{RMSEA}=.090$, 90\% CI [.081, .099], p (RMSEA $\leq .05)<.0001$ (Table 2).

Analysis of the parameter estimates revealed that the factors were highly correlated and that all standardized indices saturated the respective factor, with factor weights ranging from .46 to .72 (all $\mathrm{p}<.001)$.

Standardized residuals were calculated to identify possible sources of problems that would justify poor fit and modification indices. Four attempts were made to re-specify the model with a step-by-step correlation of the items' errors: 3 and 5; 9 and 5; 9 and 7 (Table 2).
The values of the final re-specified model, showed indices of a good fit to the theoretical Workaholism model (Figure 1), with the following results obtained: $\mathrm{X}^{2}(31, \mathrm{~N}=1,030)=211.627, \mathrm{p}<.0001, \mathrm{RMR}=.032$, $\mathrm{CFI}=.932$, RSMEA $=.075,90 \% \mathrm{CI}[.066, .085]$, $\mathrm{p}(\mathrm{RMSEA} \leq .05)<.0001$.

This reading showed that item 9 brought some instability to the model and that the fit indices without this item suggested more acceptable fit values at baseline. A moderate correlation between the dimensions; WC and WE was verified through the analysis of the matrix of standardized correlations between the latent variables.

Table 2 - Adjustment ratios of the original theoretical model and with a step-by-step correlation of the errors of the specified items - Porto, Portugal, 2019.

\begin{tabular}{lccccc}
\hline & $\mathbf{C F I}^{*}$ & $\mathbf{R M R}^{+}$ & RMSEA $^{\ddagger}$ & $\mathbf{9 0} \% \mathbf{C l}^{\S}$ & $\mathbf{P}^{\mathbf{1}}$ \\
\hline Initial model & .892 & .038 & .090 & {$[.081, .099]$} & .0001 \\
e3-e5 & .920 & .036 & .079 & {$[.070, .088]$} & .0001 \\
e9-e5 & .926 & .034 & .077 & {$[.068, .087]$} & .0001 \\
e9-e7 & .932 & .032 & .075 & {$[.066, .085]$} & .0001 \\
\hline
\end{tabular}

${ }^{*} \mathrm{CFI}$-Comparative Fit Index; ${ }^{+\mathrm{RMR}}$ - Root Mean Squared residual; ${ }^{\ddagger} \mathrm{RMSEA}-$ Root Mean Square Error Approximation; ${ }^{\S} \mathrm{Cl}$ confidence intervals; "p-value

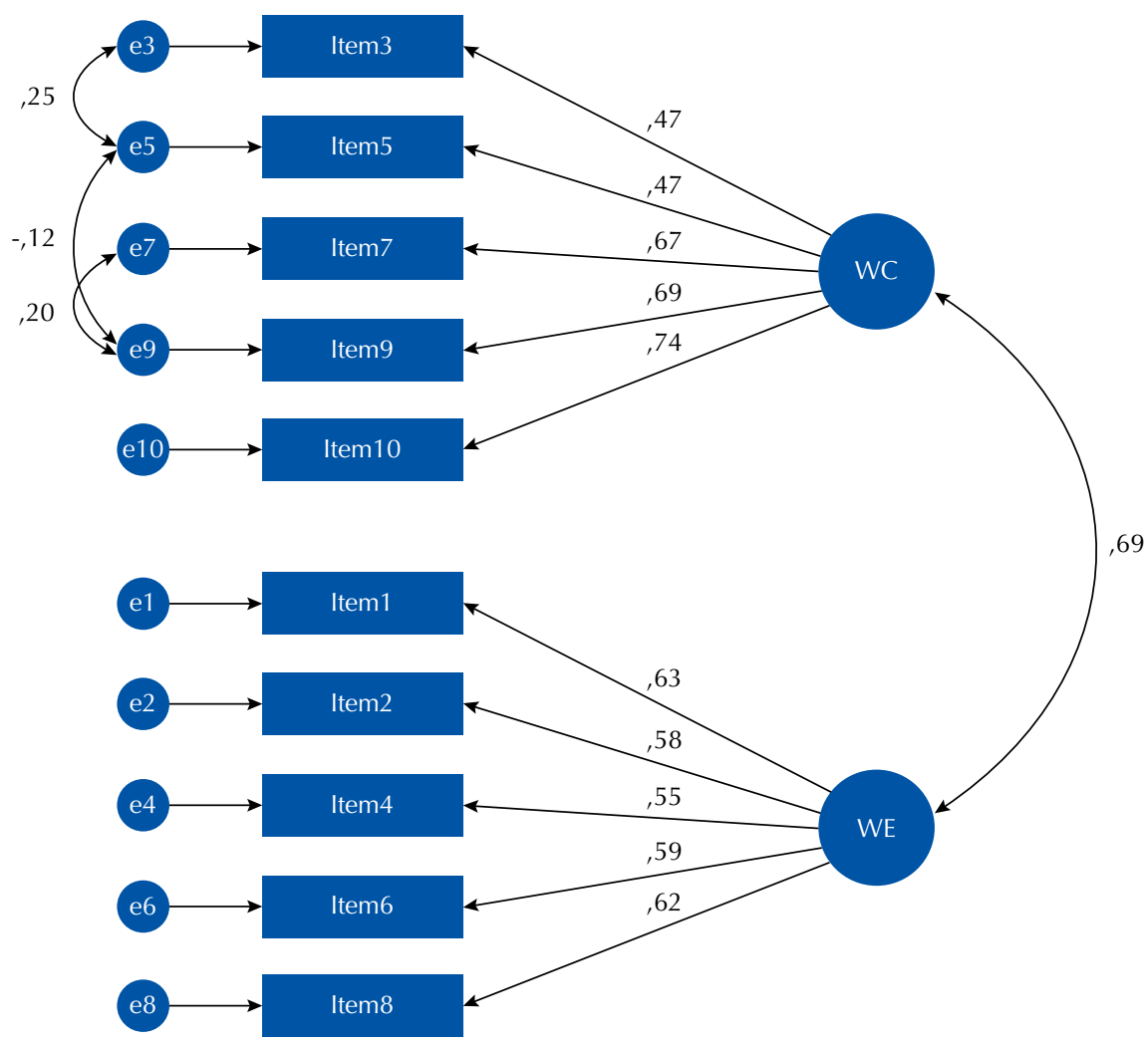

Figure 1 - The final model of the Dutch Work Addiction Scale with a sample of Portuguese nurses. 


\section{DISCUSSION}

According to the psychometric characteristics presented by the Duwas in the sample of nurses, this study identified goodness of fit values of internal consistency of the Duwas scale with the WC and WE dimensions, similar to those obtained in a sample of Dutch/Japanese workers ${ }^{(7)}(.78 / .68$ and .78/.73 for WC and WE, respectively); in a sample of Spanish/Dutch workers ${ }^{(19)}(.79 / .81$ and $.78 / .75$ for WC and $\mathrm{WE}$, respectively); and in a sample of Brazilian workers ${ }^{(18)}$ (.74 and .70 for WC and WE, respectively). In related studies conducted with nurses Cronbach's alpha values of .82 for workaholism were also identified ${ }^{(10,13)}$. Also, in Portugal, values of .75 and .65 for $\mathrm{WE}$ and $\mathrm{WC}$, respectively were reached in another study ${ }^{(23)}$.

Moreover, similar mean values were found ${ }^{(7)}$ to the findings of the study conducted with Dutch/Japanese workers ${ }^{(7)}$, namely the highest value for WE, but higher than other studies $^{(20,24)}$. Conversely, in Italian nurses higher values in $\mathrm{WC}^{(13)}$ were found.

The results of the CFA, confirmed the bidimensional factorial structure (WC and WE), grounded on the theoretical model of workaholism ${ }^{(7)}$. These results are corroborated by numerous studies conducted in several countries and various professional contexts ${ }^{(17-19,25)}$. Concerning the good fit indices of the model to the two-factor factorial model, the results found in a sample of Brazilian work$\operatorname{ers}^{(18)}$ were X2 $(34, \mathrm{~N}=324)=59.94 ; \mathrm{p}<.001 ; \mathrm{CFI}=.93$; RMSEA $=.07$, in a heterogeneous sample of Dutch work$\operatorname{ers}^{(19)} \mathrm{X} 2(34, \mathrm{~N}=2,164)=595.52 ; \mathrm{p}<.001 ; \mathrm{IFC}=.91$; RMSEA $=.09$, in a sample of Spanish workers ${ }^{(19)} \mathrm{X} 2(34$, $\mathrm{N}=550)=213.36 ; \mathrm{p}<.001 ; \mathrm{IFC}=.90 ; \mathrm{RMSEA}=.10$, and in a sample of Argentine workers ${ }^{(21)}$ Satorra-Bentler scaled chi-square test $(34, \mathrm{~N}=459)=2.35 ; \mathrm{p}<.001 ; \mathrm{CFI}=.96$; RMSEA $=.03$. We found that while the relative fit index, $\mathrm{CFI}$, showed values that confirmed the good quality of the theoretical model in all studies, in some studies, the population discrepancy indices, RMSEA, revealed marginal fit $(\mathrm{RMSEA}=.10)^{(19)}$. Overall, there is consistency in the values found in the different studies, and the results of the present study are aligned with these previous findings.
Contrarily, in a study conducted with workers from Pakistan (15.8\% nurses) ${ }^{(28)}$, there was not a good fit of the 10 -item version $\mathrm{X}^{2}(34, \mathrm{~N}=309)=100.32 ; \mathrm{p}<.000$; $\mathrm{CFI}=.85$; RMSEA $=.08$; preferring an 8 -item version (excluding items 9 and 10) which revealed goodness of fit $\left[\mathrm{X}^{2}(19, \mathrm{~N}=309)=49.49 ; \mathrm{p}<.000 ; \mathrm{CFI}=.92 ; \mathrm{RMSEA}=.07\right.$, and Cronbach Alpha values of $\mathrm{WC}=.64$ and $\mathrm{WE}=.66$.

Despite the fact that item 9- "I feel guilty when I take time off work", was found to reduce the fit of the model, considering its content and consistency, in studies developed in other countries and professional groups, it is strongly suggested that future research should test the original 10-item model. If this poor fit to the model of item 9 persists, then it should be excluded from the Portuguese version. The correlation of the three pairs of errors on the $\mathrm{WC}$ scale shows a shared variance between these items, which is likely to justify the elimination of item 9 .

The Duwas is an important instrument that provides valuable research on the phenomenon of workaholism, and its utility is proven to inform professionals and managers about the need for health-promoting interventions, posed by the constant changes in the workplace. Moreover, this instrument can be successfully applied within the framework of occupational activities developed by health services.

\section{Study Limitations}

Despite the considerable sample size, this study was not focused on variables referring to the characteristics of the organization, working methods orcare units. Thus, further research is recommended to investigate whether different organizational methods can be considered in the construct under analysis. Also, a convergent (burnout) and discriminant (engagement, satisfaction) analysis with other constructs is highly recommended to study other metric qualities.

\section{CONCLUSION}

The analysis of the psychometric characteristics of the Duwas suggests a final model indicative of goodness-tofit to the theoretical model of workaholism (if one item is excluded), guaranteeing the metric qualities of this measurement tool to be applied in a Portuguese context.

\section{RESUMO}

Objetivo: Analisar as propriedades psicométricas da Dutch Work Addiction Scale (Duwas) numa amostra de enfermeiros portugueses. Método: Foi realizado um estudo metodológico com 1.030 enfermeiros portugueses. Um questionário sociodemográfico/profissional e a Duwas foram aplicados entre outubro e dezembro de 2019. Resultados: A Análise Fatorial Confirmatória confirmou a estrutura fatorial de duas dimensões, a saber Trabalhar Excessivamente $(\alpha=0,730)$ e Trabalhar Compulsivamente $(\alpha=0,752)$, embasado no modelo teórico de workaholism; os valores de confiabilidade foram considerados adequados. Os enfermeiros apresentaram nível moderado de workaholism, com maior valor médio para Trabalhar Excessivamente. Conclusão: Os resultados levantaram a questão da adição ao trabalho e destacaram a necessidade de estudos mais aprofundados. A versão em português do Duwas apresentou boas características psicométricas e pode ser considerada um instrumento válido e útil para identificar esse problema.

\section{DESCRITORES}

Trabalho; Psicometria; Enfermeiras e Enfermeiros; Saúde do Trabalhador; Saúde Mental.

\section{RESUMEN}

Objetivo: Analizar las propiedades psicométricas de la Dutch Work Addiction Scale (Duwas) en una muestra de enfermeros portugueses. Método: Se realizó un estudio metodológico con 1.030 enfermeras portuguesas. Un cuestionario sociodemográfico/profesional y la Duwas fueron aplicados entre octubre y diciembre de 2019. Resultados: Los análisis factoriales confirmatorios confirmaron la estructura 
factorial de dos dimensiones, a saber, Trabajar en exceso $(\alpha=.730)$ y Trabajar de forma compulsiva $(\alpha=.752)$, basado en el modelo teórico de la adicción al trabajo; los valores de fiabilidad se consideraron adecuados. Los enfermeros presentaron un nivel moderado de adicción al trabajo, con un valor medio más alto para Trabajar en exceso. Conclusión: Los resultados plantearon el problema de la adicción al trabajo y destacaron la necesidad de realizar más estudios. La versión portuguesa del Duwas presentó buenas características psicométricas y puede considerarse un instrumento válido y útil para identificar este problema.

\section{DESCRIPTORES}

Trabajo; Psicometria; Enfermeras y Enfermeros; Salud Laboral; Salud Mental.

\section{REFERENCES}

1. Pinheiro LR, Carlotto MS. [Prevalence and predictors of workaholism among managers]. Rev Psicol (Santiago). 2018;27(1):1-11. Portuguese. https://doi.org/10.5354/0719-0581.2018.50742

2. Molino M, Cortese CG, Ghislieri C. Unsustainable working conditions: the association of destructive leadership, use of technology, and workload with workaholism and exhaustion. Sustainability. 2019;11(2):446. https://doi.org/10.3390/su11020446

3. Spagnoli P, Balducci C, Fabbri M, Molinaro D, Barbato G. Workaholism, intensive smartphone use, and the sleep-wake cycle: a multiple mediation analysis. Int J Environ Res Public Health. 2019;16(19):3517. https://doi.org/10.3390/ijerph16193517

4. Oates WE. Confessions of a workaholic: the facts about work addiction. New York: World Publishing; 1971.

5. Spence JT, Robbins AS. Workaholism: definition, measurement, and preliminary results. J Pers Assess. 1992;58(1):160-78. https://doi.org/10.1207/s15327752jpa5801_15

6. Ng TW, Sorensen KL, Feldman DC. Dimensions, antecedents, and consequences of workaholism: a conceptual integration and extension. J Organ Behav. 2007;28(1):111-36. https://doi.org/10.1002/job.424

7. Schaufeli WB, Shimazu A, Taris TW. Being driven to work excessively hard: the evaluation of a two-factor measure of workaholism in The Netherlands and Japan. Cross-Cultural Res. 2009;43(4):320-48. https://doi.org/10.1177/1069397109337239

8. Clark MA, Michel JS, Zhdanova L, Pui SY, Baltes BB. All work and no play? A meta-analytic examination of the correlates and outcomes of workaholism. J Nurs Manag. 2016;42(7):1836-73. https://doi.org/10.1177/0149206314522301

9. Andreassen CS. Workaholism: an overview and current status of the research. J Behav Addict. 2014;3(1):1-11. https://doi.org/10.1556/ JBA.2.2013.017

10. Ariapooran S. Sleep problems and depression in Iranian nurses: the predictive role of workaholism. Iran J Nurs Midwifery Res. 2019;24(1):30-7. https://doi.org/10.4103/ijnmr.IJNMR_188_17

11. Salanova M, López-González AA, Llorens S, Líbano M, Vicente-Herrero MT, Tomás-Salvá M. Your work may be killing you! Workaholism, sleep problems and cardiovascular risk. Work Stress. 2016;30(3):228-242. https://doi.org/10.1080/02678373.2016.1203373

12. Spagnoli P, Balducci C, Scafuri Kovalchuk L, Maiorano F, Buono C. Are engaged workaholics protected against job-related negative affect and anxiety before sleep? A study of the moderating role of gender. Int J Environ Res Public Health. 2018;15(9):1996. https://doi.org/10.3390/ijerph15091996

13. Nonnis M, Massidda D, Cuccu S, Cortese CG. The impact of workaholism on nurses' Burnout and disillusion. Open Psychol J. 2018;11(1):77-88. https://doi.org/10.2174/1874350101811010077

14. Kwak Y, Kim JS, Han Y, Seo Y. The effect of work addiction on Korean nurses' professional quality of life: a cross-sectional study. J Addict Nurs. 2018;29(2):119-27. https://doi.org/10.1097/JAN.0000000000000221

15. Torp S, Lysfjord L, Midje HH. Workaholism and work-family conflict among university academics. High Educ. 2018;76(6):1071-90. https://doi.org/10.1007/s10734-018-0247-0

16. Robinson BE. The work addiction risk test: development of a tentative measure of workaholism. Percept Mot Skills. 1999;88(1):199-210. https://doi.org/10.2466/pms.1999.88.1.199

17. Andreassen CS, Griffiths MD, Hetland J, Pallesen S. Development of a work addiction scale. Scand J Psychol. 2012;53(3):265-72. https://doi.org/10.1111/j.1467-9450.2012.00947.x

18. Carlotto MS, Del Líbano M. [Translation, adaptation and exploration of psychometric properties of "Dutch Work Addiction Scale" (DUWAS)]. Contextos Clín. 2010;3(2):141-50. Portuguese. https://doi.org/10.4013/ctc.2010.32.08

19. Del Líbano M, Llorens S, Salanova M, Schaufeli W. Validity of a brief workaholism scale. Psicothema. 2010;22(1):143-50.

20. Balducci C, Avanzi L, Consiglio C, Fraccaroli F, Schaufeli W. A cross-national study on the psychometric quality of the Italian version of the Dutch Work Addiction Scale (DUWAS). Eur J Psychol Assess. 2017;33(6):422-8. https://doi.org/10.1027/1015-5759/a000300

21. Omar A, Salessi S, Vaamonde JD, Urteaga F. Psychometric qualities of the Argentine version of the Dutch work addiction scale (DUWAS). Curr Psychol. 2021;40(2):793-803. https://doi.org/10.1007/s12144-018-9999-z

22. Lopes AL, Vieira LS. Adaptação e validação da escala de dependência de trabalho á população portuguesa [Dissertation]. Faro: Universidade Autônoma de Lisboa; 2012 [cited 2020 Jan 22]. Available from: http://hdl.handle.net/10400.1/7809

23. Pimenta AC, Semedo C. Workaholism, work engagement and Burnout: empirical distinction and their relation with job resources and demands [Dissertation]. Évora: Universidade de Évora; 2014 [cited 2020 Jan 22]. Available from: http://hdl.handle.net/10174/12955

24. Vazquez AC, Freitas CP, Cyrre A, Hutz CS, Schaufeli WB. [Validity evidence of the Dutch Work Addiction Scale - Brazilian version]. Aval Psicol. 2018;17(1):69-78. Portuguese. https://doi.org/10.15689/ap.2017.1701.08.13288

25. Beaton DE, Bombardier C, Guillemin F, Ferraz MB. Guidelines for the process of cross-cultural adaptation of self-report measures. Spine. 2000;25(24):3186-3191. https://doi.org/10.1097/00007632-200012150-00014 
26. Taber KS. The use of Cronbach's Alpha when developing and reporting research instruments. Res Sci Educ. 2018;48(6):1273-96. https://doi.org/10.1007/s11165-016-9602-2

27. Kline RB. Methodology in the social sciences: principles and practice of structural equation modeling. 4th ed. New York: Guilford; 2016.

28. Mir I, Kamal A, Masood S. Translation and validation of Dutch Workaholism Scale. Pak J Psychol Res. 2016;31(2):331-46.

Financial support

Ministério da Educação e Ciência, Fundação para a Ciência e Tecnologia UIDB/4255/202.

(cc) BY This is an open-access article distributed under the terms of the Creative Commons Attribution License. 